Brazilian Journal of Poultry Science Revista Brasileira de Ciência Avícola

\title{
Some Aspects of Chicken Behavior and Welfare
}

Review

\section{Author(s)}

Costa LS

Pereira DF

Bueno LGF $^{3}$

Pandorfi $\mathrm{H}^{4}$

${ }^{1}$ Undergraduatestudent, Campus Experimental de Tupã. Univ Estadual Paulista - UNESP

2 Professor, Campus Experimental de Tupã. Univ Estadual Paulista - UNESP

3 Professor, Campus Experimental de Dracena. Univ Estadual Paulista - UNESP

${ }^{4}$ Professor, Agricultural Engineering.

Universidade Federal Rural de Pernambuco - UFRPE

\section{Mail Adress}

E-mail: danilo@tupa.unesp.br

\section{-Keywords}

Enriched environment, precision poultry production, consumer market, productivity.

\section{ABSTRACT}

Brazil is the world leader in broiler production and export. It achieved this position mainly to its excellent supply chain structure and climate, which favor poultry and grain production throughout its territory. Although Brazilian egg production is not as important as broiler production, this segment presents great potential of increasing its share in the global market. However, as elsewhere in the world, Brazilian poultry production faces the challenge to balance two elements within its supply chain: cruelty and productivity. The consumers of the European Union (EU) are very concerned with animal welfare issues. In order to increase its share in the European market, and eventually in the world market, Brazilian poultry producers must understand the effects of production systems on poultry welfare, and try to develop systems that are suited for its climate and other production conditions. There is a consensus that the natural behaviors performed by poultry in intensive production systems allow better welfare. This objective of this review is to present scientific research studies that relate different behaviors to chicken welfare. Poultry behavior is a reflex of their welfare status at a particular moment, and it is related to internal (physiological) and external (environmental) factors. Several natural behaviors that favor welfare, as well as undesirable behaviors, may be stimulated by environmental enrichment. The correct interpretation of the behaviors expressed by poultry, including their frequency, duration, and sequence, may be used to estimate their welfare.

Animal production is an import sector of Brazilian economy. It significantly contributes to the Gross Domestic Product (GDP), in terms of products destined both to domestic consumption and exports. New technologies applied to products and management practices have been developed for field application, aiming at improving producers' productivity and profitability. In order to comply with the European Union's (EU) guidelines for animal protein production, Brazilian poultry production needs to undergo a process of adaptation.

In May, 2007, the EU Commission established its new guidelines for animal welfare in poultry production, pressured by consumer demand. In the EU, there is a growing concern among consumers as to how poultry are reared and slaughtered. European consumers are in the fore front of the demand of high quality products produced with under better welfare conditions, and have spread this concern throughout the world. Beaumont et al. (2010) mentioned that European consumers frequently perceive that standard commercial poultry production has poor animal welfare practices.

According to Nääs et al. (2008), Brazilian poultry production today needs to find a balance between cruelty and productivity. In fact, ensuring animal welfare may provide better financial results, as it increases the producer's profit margins and allows maintaining 
Brazilian chicken export quotas to the EU. França (2008) noted that biological studies that define ethical limits and guidelines for poultry production foster the development of new production practices that may ensure good product quality and productivity without putting bird welfare at risk.

Gonyou (1994) states that, when animal welfare started to be studied, the only behavioral factors considered were those related to feeding and reproduction. These first studies used as indicators of animal welfare reduced life expectancy, impaired growth, impaired reproduction, body damage, disease, immunosuppression, adrenal activity, behavior anomalies, and self-narcotization (Broom, 1991). However, current studies evaluate additional indicators, such as natural behaviors, behavioral needs, preferences, behavioral problems, emotional state, cognitive abilities, etc.

In the field of ethology, the expression of natural behavior is a frequently used tool used to estimate the welfare of poultry destined to human consumption. According to Bracke \& Hopster (2006), natural behavior can be defined as the behavior the animal normally presents when exposed to conditions similar to its natural habitat. Natural behaviors are pleasurable and promote biological functions that are meaningful to the animal's welfare. The definition of natural behavior, though, does not include the bird's behavior when sick, in flight or during aggression, since these are not considered pleasurable situations.

Considering layer behavioral needs in the design of housing facilities optimize their welfare. Mishra et al. (2005) verified that ISA Brown layers spent, during 24 hours, around $97 \%$ of the time in the nest, feeding, walking, resting, or dust bathing, and that $57 \%$ of these behaviors did not depend on environmental enrichment. It was also observed that hens had preferred behavioral sequences, which included foraging and comfort behaviors, such as wingstretching and preening.

The present review aims at discussing, albeit not exhaustively, scientific research studies on the behavior of Gallusgallus domesticus and its relationship to welfare. The following behaviors are reviewed: feather pecking, scratching, dust bathing, nesting, locomotion activities, and aggressive behaviors. These behaviors are the most frequently observed in commercial broiler, broiler breeder, and layer farming, and therefore, monitoring their incidence may contribute to measure poultry welfare.

\section{DUST BATHING}

Dust bathing includes a sequence of behavioral components. Firstly, the bird pecks and scratches the potential dust bathing place, and then sits on a spot and starts to gather loose substrate particles around its body. Still sitting, the bird flaps its wings to spread the particles in the air and to allow them to settle on its feathers. It then lies down, rubbing its neck and the sides of body on the substrate, and finally shakes itself to remove the particles.

According to Duncan (1998), dust bathing removes external parasites and improves feather conditions, similar to feather preening and may be considered a natural behavior (Shields \& Duncan, 2004). These authors mention that the main function of dust bathing is to balance lipid levels in the feathers. There are several internal and external factors, including light, substrate, presence of parasites, heat, and pleasure, that elicit dust bathing. For instance, the frequency of dust bathing is related to the bird's circadian rhythm (Vestergaard, 1982). The sight of powdered substrates (Petherick et al., 1995), and the presence of light or heat (Duncan, 1998) may also stimulate dust bathing.

According to Pereira et al. (2007), it is a mechanism of heat loss by conduction. This sequence of movements, which involves body rotation and leg stretching, may also be considered an exercise, at it makes leg muscles stronger, thereby preventing leg deformities and walking incapacity (Shields et al., 2004). It is also a social behavior, because birds commonly express this behavior in groups (Olsson et al., 2002).

In the study of Shields et al. (2004) with broilers, average duration of dust baths was around 15 minutes, and no preference among the four types of substrate tested (pinewood shavings, rice husks, granulated construction sand, and recycled paper) were detected. However, during one hour of observation, the frequency of litter pecking - a behavior that precedes dust bathing - was significantly higher in sand (534 pecks) than in paper, rice hulls or wood shavings (46, 54, and 76 pecks, respectively). These preference differences suggest that the motivation to find and ingest small grits in sand to aid digestion remains present even if broilers no longer need them to digest commercial feeds. Interestingly, none of the birds in that study preferred rice husks to display the complete dust bathing behavioral sequence.

Differently from Shields et al. (2004), Wall et al. (2008) observed that Hy-Line White and Hy-Line Brown layers housed in furnished cages preferred 
sawdust, and not sand, to dust bathe. However, no differences were detected in the time they remained on each substrate. Interestingly, when Hy-Line Brown birds dust-bathed, there was a higher concentration of particles in the air and they presented more pecking lesions, indicating that, independently from substrate, this strain was more aggressive when expressing this behavior. This result stresses the importance of genetics and its relation with the environment when aggressive behavior is considered (Blokhuis et al., 2007).

\section{NESTING}

This behavior precedes ovi position, and consists in the search of an adequate place to lay the egg. Hens rapidly get in and out of the nest boxes, or build their nest on the litter. At the time of lay, the hen enters the nest and remains there.

According to Duncan (1998), nesting behavior is an example of natural behavior with a predominantly internal motivation, that is, it does not depend on the external environment. This behavior is expressed or attempted to be expressed $1 \mathrm{~h}$ to $1 \mathrm{~h} 30$ before lay. If the bird is not able to build the nest, this need is frustrated and the hen demonstrates its frustration sitting and not performing any activity.

Zupan et al. (2008a) observed that layers that do not have access to suitable nest sites may present an elaborate sequence of nest seeking and building behaviors one hour before lay, with apparent frustration signs, such as excessive locomotion and exploratory activities (Cooper \& Appleby, 1996), as well as a special vocalization, called gackel-call (Zimmerman et al., 2000). In addition, frustration may be physiologically expressed by egg retention in the eggshell gland (Hughes et al., 1986), resulting in an extra calcium layer on the eggshell (Reynard \& Savory, 1999). According to Keeling (2004), these signs indicate that the hen's welfare was compromised by the lack of a suitable nest.

\section{LOCOMOTION ACTIVITIES}

Studies have shown that the expression of other natural behaviors, such as perching and walking on ramps, may improve poultry walking ability (Mench et al., 2001).

Bracke \& Hopster (2006) mention that some species-unspecific behaviors, that is, behavior that are expressed by several species, such as playing, walking, stretching the limbs, turning, standing up and lying down normally, are highly beneficial to welfare.
Buijs et al. (2010) observed that the duration of the expression of the behaviors of standing, lying, scratching the litter or feeding were not influenced by stocking density in broiler flocks; however, the duration of sitting and preening was shorter at higher stocking densities, as well as walking, which was increasingly reduced during the last weeks of the flock.

María et al. (2004) associated reduced locomotion activity with increased stress caused by the frustration of the expression of some behaviors, such as lack of access to nests (Duncan, 1998), or by high environmental temperatures, in an attempt to exchange heat with the litter.

According to Leone \& Estévez (2008), there are several benefits of environmental enrichment to poultry, including more even distribution of birds in the space available, which allows more activity and locomotion and reduces disturbances and aggression, as well as fear and stress.

Using a preference test, Zupan et al. (2008b) evaluated nest types (box or litter tray) and laying sites for layers. No differences were observed in the number of times layers entered the different nest types, but their restlessness decreased with laying experience.

\section{SCRATCHING}

The behavior of scratching is expressed when the bird scratches the litter with its feet in a backward movement, and pecks the litter in search of food. According to Bracke \& Hopster (2006), this behavior is very important to the bird because, its higher intensity, duration, and incidence indicate better bird welfare. Wiepkema (1987) developed a model relating the expression of a behavior that results in welfare (Sollwert) with how its expression is cognitively perceived by a bird (Istwert); the difference between these two parameters would determine how the bird responds to the environment. When layers are housed in battery cages in commercial farms, there are large differences between Sollwert and Istwert because, among other deprivations, there is no litter available for scratching.

One of the consequences of the frustration of scratching behavior is the negative behavior of feather pecking. Haas et al. (2010) observed that poultry may redirect their scratching behavior to pecking the feathers of other birds when their foraging possibilities are limited. According to the study of Nicol et al. (2009), chickens prefer environments that give them the opportunity of scratching and preening. 


\section{AGGRESSIVE BEHAVIOR}

In addition of expressing behaviors that may contribute for their welfare, that is, those promoting physical, psychological, and social benefits, chickens may also express negative behaviors, detrimental to their welfare, when frustrated or frightened.

Freedom from fear and distress is one of the five animal freedoms established by the UK government in 1965, and later adopted by several international bodies as an animal welfare paradigm. According to Broom (1991), fear is a preparation for danger or a response to a detectable danger. It is associated with freezing behavior, tonic immobility, scape attempts, aggression, adrenal cortex activity, heart-rate elevation, and effects on meat quality. Fear reactions range from a mild state of alert to extreme panic, with behaviors indicating suffering and welfare impairment (Duncan, 1998). Beaumont et al. (2006) states that inappropriate fear levels should be prevented. When fear is extremely high, there may panic, high mortality, and hindering of human-animal relationships, whereas excessively low levels are detrimental to the animal, because fear is a natural response that allows animals to react to danger.

Cannibalism is a behavior detrimental to bird welfare, particularly because it causes pain and injuries. It is related to severe feather pecking and some authors believe it is a result of the genetic selection for the improvement of individual performance as opposed to social and natural behaviors (Merir \& Aggrey, 2003). Rooijen (2010) observed that some commercial layer strains still carry the wild genotype that has this behavior; however, environmental stimuli are required for its expression.

Tablant et al. (2000) evaluated the incidence of cannibalism and its relationship with mortality in a commercial layer farm, and observed that it was the third cause of mortality in Babcock White Leghorns between 21 and 54 weeks of age reared in cages at a stocking density of $150 \mathrm{~cm}^{2}$. Most lesions were observed in the cloaca after the peak of egg production. Other major mortality causes were peritonitis, neoplasias, and hypocalcemia.

Feather pecking was observed in $77 \%$ of the commercial layer farms surveyed by Huber-Eicher \& Sebo (2001).This behavior involves pecking and possible removal of the feathers of one bird by another (Hoffmeyer, 1969), and it is considered by Bracke \& Hopster (2006) a symptom of negative welfare status. According to McAdie \& Keeling (2002), feather pecking may be classified as: i) gentle, in which feathers are nibbled and not pulled out, and the recipient bird does not react; and ii) severe, in which feather are vigorously pulled and some may be removed, and the recipient bird often reacts. While gentle feather pecking may be considered a normal exploratory behavior, severe feather pecking impairs bird welfare because it causes pain (Gentle \& Hunter, 1990), and the blood from the injuries may lead to cannibalism (Hughes \& Duncan, 1972).

In addition of a welfare problem, feather pecking economically affects the egg production industry (Brumberg et al., 2011), and therefore, measures to prevent such behavior are needed. One possibility is genetic selection, but it is not efficient in all strains, as the genetic mechanism associated to feather pecking still needs to be fully elucidated. Labouriau et al. (2009) observed the expression of feather pecking in layers has been extensively studied, but further research on its prevention is required. Those authors observed this behavior along eight generation of layers, which evidences that there is a dominant allele affecting this behavior, and that this gene is transmitted over generations.

According to Harlander-Matauschek et al. (2006), feather pecking may lead to feather ingestion, stimulating feed passage through the digestive system in the same manner as insoluble fiber.

Also, feather pecking is usually considered a result of the frustration in expressing scratching behavior, depending on litter material (Bracke \& Hopster, 2006) or dust bathing (Shields et al., 2004), as both behaviors have a component associated to pecking movements. When there are no natural substrates for pecking, the bird replaces them by feathers (Johnsen \& Vestergaard, 1996). According to Dixon (2008), severe feather pecking results from motivational frustrations related to inadequate litter material, and not to dust bathing, as the morphology of feather pecking is similar to that associated to scratching, which is different from those presented during dust bathing or feather preening.

In the studies of van Krimpem etal. (2007) and Dickey et al. (2010), different particle sizes and ingredient levels in layer diets did not influence the expression of feather pecking. However, van Krimpem et al. (2007) found that layers fed coarser diets, independently of dietary energy and non-starch polysaccharide levels, remained longer at the feeders and engaged less in feather pecking behavior than those fed finer diets.

Bilcík \& Keeling (1999) evaluated skin lesions in layers pecked by others as a function of age, group size, and stocking density, and verified that birds in large groups were the most affected by severe pecking, feather pulling, and cannibalism at any age. Moreover, 
lighter and younger hens tend to be more affected by this aggressive behavior.

Ramadan \& von Borell (2008) observed that hens reared in cages tended to be more restless and present worse feathering, despite not finding any significant differences in the expression of feather pulling as compared to those reared in an enriched environment. Also, the authors observed that feather pecking was more frequent in the afternoon, and that the wings and tail were the most affected body areas.

\section{FINAL CONSIDERATIONS}

Poultry behavior is a reflex of their welfare status at a particular moment, and it is related to internal (physiological) and external (environmental) factors. Several natural behaviors that favor welfare, as well as undesirable behaviors, may be stimulated by environmental enrichment. The correct interpretation of the behaviors expressed by poultry, including their frequency, duration, and sequence, may be used to estimate their welfare.

\section{ACKNOWLEDGEMENTS}

The authors thank FAPESP for the aid provided to the author for publishing this paper.

\section{REFERENCES}

Beaumont C, Lebihan-Duval E, Mignon-Grasteau S, Leterrirer C. The European experience in poultry welfare - A decade ahead. Poultry Science 2010;89:825-831

Bilcik B, Keeling LJ. Changes in feather condition in relation to feather pecking and aggressive behavior in laying hens. British Poultry Science 1999; 40(4): 444-451

Blokuis HJ, van Niekerk FT, Bessei W, Elson A, Guèmenè D, Kjaer JB, Levrino MGA, Nicol CJ, Tauson R, Weeks CA, van der Weerd HA. The Lay Wel project: Welfare implications of changes in production systems for laying hens. World's Poultry Science 2007; 63:101-114.

Bracke MBM, Hopster $\mathrm{H}$. Assessing the importance of natural behavior for animal welfare. Journal of Agricultural and Environmental Ethics 2006; 19: 77-89.

Broom DM. Animal welfare: concepts and measurement. Journal of Animal Science $1991 ; 69: 4167-75$

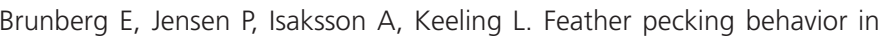
laying hens: hypothalamic gene expression in birds performing and receiving pecks. Poultry Science 2011; 90:1145-52.

Buijs S, Keeling LJ, Vangestel C, Jeroen B, Vangeyte J, Tuyttens FAM. Resting or hiding? Why broiler chickens stay near walls and how density affects this. Applied Animal Behavior Science 2010; 124:97-103.

Cooper JJ, Appleby MC. Individual variation in pre-laying behavior and the incidence of floor eggs. British Poultry Science 1996: 37:245-53.
Dickey ER, Bregendahl K, Stalder K, Fitzgerald R, Johnson AK. Effects of a premoltcalcium and low-energy molt program on laying hen behavior and heterophil-to-lymphocyte ratios. Poultry Science 2010; 89:2317-2325.

Dixon LM. An investigation into the motivation behind abnormal feather pecking behavior in laying hens [thesis]. Ontario (CA): University of Guelph; 2008.

Duncan IJH. Behavior and Behavioral needs. Poultry Science1998; 77:176672

França JM. Exigências dos diferentes programas de certificação e auditoria para bem-estar em frangos de corte. Anais da Conferência APINCO 2008 de Ciência e Tecnologia Avícolas; 2008; Santos, São Paulo. Brasil p.129-34

Gentle MJ, Hunter LN. Physiological and behavioral responses associated with feather removal in Gallus gallusvardomesticus. Research in Veterinary Science 1990; 50:95-101.

Gonyou HW. Why the study of animal behavior is associated with the animal. Journal of Animal Science 1994; 72(21): 2171-2177.

Haas EN, Nielsen BL, Buitenhus AJ, Rodenburg TB. Selection on feather pecking affects response to novelty and foraging behavior in laying hens. Applied Animal Behavior Science 2010;124:90-96.

Harlander-Matauschek A, Baes C, Bessei W. The demand of laying hens for feathers and wood shavings. Applied Animal Behavior Science 2006 101:102-110.

Hoffmeyer I. Feather pecking in pheasants - an ethological approach to the problem. Danish Review of Game Biology. Rønde, Denmark: Vildtbiologisk Station; 1969, p. 36

Huber-Eicher B, Sebo F. The prevalence of feather pecking and development in commercial flocks of laying hens. Applied Animal Behavior Science $2001 ; 4: 223-231$

Hughes BO, Duncan IJH. The influence of strain and environmental factors upon feather pecking and cannibalism in fowls. British Poultry Science 1972; 20:163-181.

Hughes BO, Gilbert AB, Brown MF. Categorization and causes of abnormal egg shells: Relationship with stress. British Poultry Science 1986; $27 \cdot 325-337$.

Johnsen PF, Vestergaard KS. Dust bathing and pecking behavior in chicks from a high and a low feather pecking line of laying hens. Applied Animal Behavior Science 1996; 49:237-246.

Keeling LJ. Nesting, perching and dust bathing. In: Perry GC. Welfare of the Laying Hen. Wallingford: CAB International; 2004, p. 203-213.

Labouriau R, Kjaer JB, Abreu GCG, Hedegaard J, Buitenhuis AJ. Analysis of severe feather pecking behavior in high feather pecking selection line. Poultry Science 2009; 88:2052-2062.

Leone EH, Estévez, I. Economic and welfare benefits of environmental enrichment for broiler breeders. Poultry Science 2008; 87:14-21.

María GA, Escós J, Alados CL. Complexity of behavioral sequences and their relation to stress conditions in chickens (Gallus gallusdomesticus) a non-invasive technique to evaluate animal welfare. Applied Animal Behavior Science 2004;86:93-104

McAdie TM, Keeling $\amalg$. The social transmission of feather pecking in laying hens: effects of environment and age. Applied Animal Behavior Science 2002; 75:147-159

Mench JA, Garner JP, Falcone C. Behavioral activity and its effects on leg problems on broiler chickens. Proceeding of the 6th European Symposium on Poultry Welfare; 2001; Zollikofen. Switerland: ZoWorld's Poultry Science Association; 2001, p. 152-156. 
Merir WM, Aggrey SE. Poultry genetics, breeding and biotechnology. Washington: $\mathrm{CABI} ; 2003$.

Mishra A, Koene P, Schouten W, Spruijt B, van Beek P, Metz JHM. Temporal and sequential structure of behavior and facility usage of laying hens in an enriched environment. Poultry Science 2005; 84:979-991.

Nääs IA, Pereira DF, Moura DJ, Silva RBTR. Princípios de bem-estar animal e sua aplicação na cadeia avícola. Conferência APINCO 2008 de Ciência e Tecnologia Avícolas; 2008; Santos, São Paulo. Brasil.

Nicol CJ, Caplen G, Edgar J, Browne WJ. Associations between welfare indicators and environmental choice in laying hens. Animal Behavior 2009; 78:413-424

Olsson IAS, Duncan IJH, Keeling LJ, Widowski TM. How important is social facilitation for dustbath in laying hens? Applied Animal Behavior Science 2002; 79:285-297.

Pereira DF, Nääs IA, Salgado DA, Gaspar CR, Bighi CA, Penha NLJ. Correlations among behavior performance and environment in broiler breeders using multivariate analysis. Brazilian Journal of Poultry Science 2007; 9(4): 207-213.

Petherick JC, Seawright E, Waddington D, Duncan IJH, Murphy LB. The role of perception in the causation of dust bathing behavior in domestic fowl. Animal Behavior 1995; 49:1521-1530.

Ramadan SG, von Borell E. Role of loose feathers on the development of feather pecking in laying hens. British Poultry Science 2008; 49(3):250256.

Reynard M, Savory CJ. Stress-induced oviposition delays in laying hens: Duration and consequences for eggshell quality. British Poultry Science 1999; 40:585-591.

Rooijen J. Is feather pecking in laying hens a by-product of artificial selection? Applied Animal Behavior Science 2010; 122:133.

Shields SJ, Duncan IJH. An HSUS Report: A comparison of the welfare of hens in battery cages and alternative systems. Washington: The Humane Society of the United States; 2004.

Shields SJ, Remena RA, Garner JP, Mench JA. Dust bathing by broiler chickens: a comparison of preference for four different substrates. Applied Animal Behavior Science 2004; 87:69-82.

Tablant NL, Vaillancourt JP, Martin SW, Shoukri M, Estevez I. Spatial distribution of cannibalism mortalities in commercial laying hens. Poultry Science 2000; 79:705-708.

vanKrimpen MM, Kwakkel RP, van der Peet-Schwering CMC, Den Hartog LA, Verstegen MWA. Low dietary energy concentration, high nonstarch polysaccharide concentration, and coarse particle sizes of no starch polysaccharides affect the behavior of feather pecking-prone laying hens. Poultry Science 2008; 87:485-496.

Vestergaard K. Dust bathing in domestic fowl: diurnal rhythm and dust deprivation. Applied Animal Ethology 1982;8:487-495.

Wall $H$, Tauson R, Elwinger K. Effects of litter substrate and genotype on layers' use of litter, exterior appearance, and heterophil: lymphocyte ratios in furnished cages. Poultry Science 2008; 87:2458-2465.

Wiepkema PR. Behavioral Aspects of Stress. In: Wiepkema PR, van Adrichem PWM, editors. Biology of stress in farm animals: an integrative approach. Dordrecht: Martinus Nijhoff; 1987, p. 113-133.

Zimmerman PH, Koene $\mathrm{P}$, van Hooff JARAM. Thwarting of behavior in different contexts and the gackel-call in the laying hens. Applied Animal Behavior Science 2000; 69:255-264.
Zupan M, Kruschwitz A, Buchwalder T, Huber-Eicher B, Stuhec I. Comparison of the Prelaying Behavior of Nest Layers and Litter Layers. Poultry Science 2008b; 87:399-404.

Zupan M, Kruschwitz A, Buchwalder T, Huber-Eicher B, Stuhec I. Environment, well-being and behavior: comparison of the prelaying behavior of nest layers and litter layers. Poultry Science 2008a; 87:399404. 